\title{
Hvorfor sykmeldes ryggpasienter?
}

\section{Vond rygg er fortsatt blant de \\ hyppigste årsaker til sykefravær, \\ til tross for at gjeldende retnings- \\ linjer anbefaler vanlig aktivitet ved \\ uspesifikke ryggplager.}

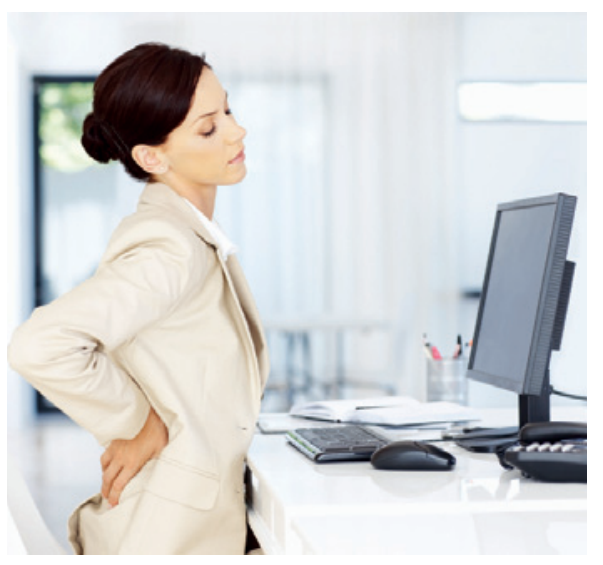

Illustrasjonsfoto Istockphoto
I en systematisk oversiktsartikkel har vi belyst hvilke faktorer som påvirker legenes vurderinger av arbeidsførhet hos ryggpasienter (1).

Ethvert sykefraværstilfelle påvirkes av fire aktører: den sykmeldte, legen, arbeidsplassen og samfunnet. Faktorer knyttet til den sykmeldte, arbeidsplassen og samfunnet er beskrevet i mange artikler, men det finnes få artikler om legens rolle. Gjennom systematiske søk i fire databaser ble 1419 potensielle studier identifisert, men bare 11 av disse tilfredsstilte inklusjonskriteriene for vår studie.

Av kjennetegn ved pasientene som legen legger mest vekt på $i$ vurderingen av arbeidsuførhet, var deres forventninger, tilstedeværelse av kliniske funn og i hvilken grad legen oppfattet at det var mulighet for støtte og tilrettelegging på arbeidsplassen. Egenskaper hos legen som påvirket vurderingen, var særlig kunnskaper og holdninger til ryggplager. Leger som var engstelige for å fremprovosere smerter og mente dette kunne være farlig, var mer tilbøyelige til å sykmelde. Leger som følte seg ukomfortable i portvaktrollen og syntes uspesifikke helseplager generelt var vanskelig å håndtere, var også mer tilbøyelige til å sykmelde.

Vi konkluderer med at den nære forbindelsen mellom lege og pasient, som i de fleste sammenhenger ellers betraktes som et gode, kan være et hinder for at retningslinjene $\mathrm{i}$ vurderingen av sykmelding blir fulgt. Leger kvier seg for å la være å imøtekomme pasientenes ønsker og synes å trenge mer kunnskap om god pasientkommunikasjon for å kunne formidle nye holdninger på en positiv måte. Tidligere studier har vist at legene har god kunnskap om og gode holdninger til ryggplager, men det kan se ut som at de ikke klarer å formidle dette godt nok til sine pasienter.

\section{Erik L. Werner}

loewern@online.no

Allmennmedisinsk forskningsenhet i Bergen Uni Research, Uni helse

\section{Litteratur}

1. Werner EL, Côté P. Fullen BM et al. Physicians determinants for sick-listing LBP patients: a systematic review. Clin J Pain 2011; e-publisert 31.8.

\section{Mange leger er utbrent}

\section{Utbrenthet og redusert livskvalitet er vanlig blant amerikanske leger. Arbeidstilfredsheten er avhengig av medisinsk kompetanse og jobberfaring.}

Stress hos leger kan ramme pasientene i form av feilbehandling og minsket tillit til helsevesenet. Flere faktorer kan gjøre leger stresset. Dette viser en stor undersøkelse med over 16000 leger ansatt ved indremedisinske sykehusavdelinger over hele USA (1).

Egenvurdert livskvalitet var «så dårlig som den kunne være» eller «noe dårlig» hos $14,8 \%$ av legene. Utbrenthet og høyt nivå av emosjonell utmattelse ble rapportert hos rundt halvparten. Leger med store studielån var oftere enn andre plaget av utbrenthet og lav livskvalitet. Leger med høy kompetanse innen sitt fagfelt anga bedre livskvalitet, mer velvære og mer selvtillit enn de øvrige. Spesialister $\mathrm{i}$ indremedisin med flere års erfaring anga mer trivsel enn nyutdannede leger.

- Utbrenthet hos leger er bekymringsfullt, ikke bare for den enkelte lege, men også for pasientbehandlingen. Leger har rapportert at de er mindre tålmodige og mer frustrerte i pasientmøtene når de er slitne, og det er funnet økt risiko for feilmedisinering ved utbrenthet, sier forsker Karin Isaksson Rø ved Legeforeningens forskningsinstitutt og ved Ressurssenter Villa Sana, Modum Bad.

- Denne tverrsnittsstudien er en av få der man har undersøkt sammenhengen mellom legers helse, livskvalitet, økonomiske forpliktelser og objektivt målt kunnskapsnivå. Resultatene er vanskelige å oversette direkte til norske forhold, og vi trenger derfor liknende undersøkelser også i Norge. Longitudinelle studier er avgjørende for å få mer kunnskap om årsaksforhold, sier Isaksson Rø.

\section{Tor Atle Rosness}

tor.rosness@aldringoghelse.no

Nasjonalt kompetansesenter for demens

\section{Litteratur}

1. West CP, Shanafelt TD, Kolars JC. Quality of life, burnout, educational debt, and medical knowledge among internal medicine residents. JAMA 2011; 306: $952-60$.

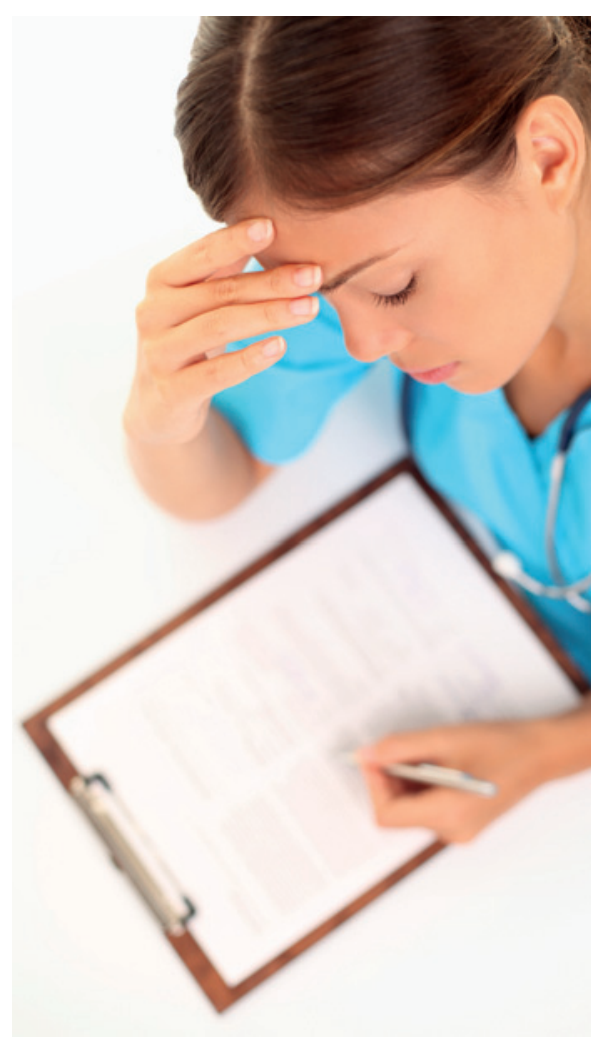

Illustrasjonsfoto Istockphoto 